\title{
"The strong influence of sound corporate governance on economic Growth: evidence from Zimbabwe"
}

\begin{tabular}{|c|c|}
\hline AUTHORS & Alexander Maune \\
\hline ARTICLE INFO & $\begin{array}{l}\text { Alexander Maune (2017). The strong influence of sound corporate governance } \\
\text { on economic Growth: evidence from Zimbabwe . Problems and Perspectives in } \\
\text { Management, 15(2-2), 445-455. doi:10.21511/ppm.15(2-2).2017.13 }\end{array}$ \\
\hline DOI & http://dx.doi.org/10.21511/ppm.15(2-2).2017.13 \\
\hline RELEASED ON & Friday, 01 September 2017 \\
\hline RECEIVED ON & Thursday, 01 June 2017 \\
\hline ACCEPTED ON & Thursday, 22 June 2017 \\
\hline LICENSE & $\begin{array}{l}(c)) \text { EY-NC } \\
\text { This work is licensed under a Creative Commons Attribution-NonCommercial } 4.0 \\
\text { International License }\end{array}$ \\
\hline JOURNAL & "Problems and Perspectives in Management" \\
\hline ISSN PRINT & $1727-7051$ \\
\hline ISSN ONLINE & $1810-5467$ \\
\hline PUBLISHER & LLC "Consulting Publishing Company "Business Perspectives" \\
\hline FOUNDER & LLC "Consulting Publishing Company "Business Perspectives" \\
\hline
\end{tabular}

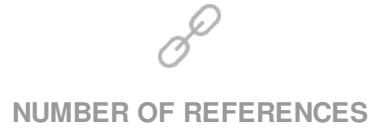

45
NUMBER OF FIGURES

1
NUMBER OF TABLES

7

(C) The author(s) 2023. This publication is an open access article. 


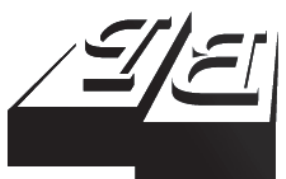

BUSINESS PERSPECTIVES

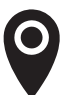

LLC "CPC "Business Perspectives" Hryhorii Skovoroda lane, 10, Sumy, 40022, Ukraine

www.businessperspectives.org

Received on: $1^{\text {st }}$ of June, 2017

Accepted on: $22^{\text {nd }}$ of June, 2017

(C) Alexander Maune, 2017

Alexander Maune, College of Economic and Management Sciences, University of South Africa.

\section{(ㄷ)(1) $(8)$}

This is an Open Access article, distributed under the terms of the Creative Commons Attribution-NonCommercial 4.0 International license, which permits re-use, distribution, and reproduction, provided the materials aren't used for commercial purposes and the original work is properly cited.

\section{THE STRONG INFLUENCE OF SOUND CORPORATE GOVERNANCE ON ECONOMIC GROWTH: EVIDENCE FROM ZIMBABWE}

\begin{abstract}
The study examined the impact of sound corporate governance on economic growth in Zimbabwe using an econometric model. A multiple linear regression analysis was employed to examine the relationship. Secondary data for the period 1968 to 2015 was collected from World Bank's Worldwide Governance and World Development Indicators databases. It was found that sound corporate governance is significantly correlated to economic growth in Zimbabwe in a positive and negative manner with a p-value of 0.000023235 at $5 \%$ level of confidence. On one hand, control of corruption is negatively significantly related to economic growth and, on the other hand, political stability and absence of violence/terrorism positively significantly related to economic growth. Government effectiveness, regulatory quality, rule of law and voice and accountability are insignificant in influencing economic growth in Zimbabwe at 5\% level of significance. The findings from this article will assist policy formulation, policy implementation and future research. This article, however, is of great importance to government, private sector and the academia.
\end{abstract}

\section{Keywords}

corporate governance, economic growth, economic development, gross domestic product, investor protection, Zimbabwe

\section{JEL Classification G34, O11}

\section{INTRODUCTION}

How critical is sound corporate governance for economic growth given the attention paid to it in the aftermath of corporate scandals such as Enron, WorldCom and the global financial crisis and whether it can be considered a panacea for economic challenges facing the developing world in general and Zimbabwe in specific? One is forced to ask. To the World Bank (2017, p. 66), studies by Klapper and Love (2004), Claessens (2006), Kutan (2015) and Asker et al. (2015) provide evidence that achieving sound corporate governance promotes economic growth and development. World Bank (2017, p. 66) states that "sound corporate governance is the optimal balance between controlling shareholders, minority shareholders, company managers and market regulators". The growth in attention that has been devoted to corporate governance throughout the whole world is neither new nor surprising (World Bank, 2017). According to World Bank (2017), the Organization for Economic Co-operation and Development and the American Law Institute, principles of corporate governance have formed foundational references for sound corporate governance in the world over among others. 
These principles guarantee a minimum standard through which companies are directed and controlled. Okpara (2011) reasons that sound corporate governance principles provide shareholders with judicial recourse in case of violation of rules. Sound corporate governance provides investors with the comfort needed to finance business ventures of others without exerting direct control over the affairs of the company (Shleifer \& Vishny, 1986; La Porta, Lopez-de-Silanes, Shleifer, \& Vishny, 2000; Holderness, 2003; Dyck \& Zingales, 2004). Sound corporate governance results in easier access to capital, company growth, generation of tax revenues, as well as employment creation (Arora, 2014; Rupeika-Apoga, 2014). To Gompers et al. (2003), Brown and Caylor (2009) and Ammann et al. (2011), sound corporate governance also contributes to value maximization throughout the life of a company. Sound corporate governance gives executives and managers the authority to efficiently and sufficiently apply their skills and business acumen (Grossman \& Hart, 1982; Denis \& Serrano, 1996; Aggarwal et al., 2009). Bebchuk (2013) claims that sound corporate governance ensures that proper internal structures, processes and adequate risk management measures are in place.

Research studies have also shown positive affect of sound corporate governance on equity returns and efficiency (Ates et al., 2014; Lan \& Varottil, 2015; Liljeblom \& Maury, 2015). Policy-makers need to appreciate the role of sound corporate governance in sustainable economic growth and development (Posner, 1983; La Porta et al., 1996). Sound corporate governance principles are critical elements in restoring and boasting investor confidence and trust (Tiwari, 2010). De Paula (2003) cited by Tiwari (2010, p. 2) states that sound corporate governance enhances economic growth and development through two mechanisms which are associated with financing and investment and economic system efficiency. This study seeks to examine the strong influence of sound corporate governance on economic growth in Zimbabwe.

The remainder of the article is structured as follows: section 1 provides the literature review; section 2 describes research methodology; section 3 contains data analysis and interpretation and last section concludes.

\section{LITERATURE REVIEW}

\subsection{Definition of corporate governance}

Weimer and Pape (1999) cited by Tiwari (2010) "[define] corporate governance as a country specific framework of legal, institutional and cultural factors, shaping the patterns of influence that stakeholders exert on managerial decision making" (p. 1). To Charreaux (1997) cited by Tiwari (2010), "corporate governance [are] the organizational mechanisms which have the effect of bounding the powers and of influencing the decisions of the managers, in other words, the mechanisms which "govern" their behavior and define their discretionary space" (p. 1). However, to Pass (2004) cited by Tiwari (2010), "corporate governance deals with the duties and responsibilities of a company's board of directors in managing the company and their relationships with the shareholders of the company and the stakeholder groups" (p. 1). For more definitions of corporate governance, see Maune (in progress). Maune
(2014) gives a detailed overview of corporate governance in Zimbabwe. Maune's (2014) study took a qualitative approach to provide Zimbabwe's corporate governance overview with findings showing that Zimbabwe remains amongst a few countries that do not have a national code of corporate governance. Corporate governance practice in Zimbabwe has been regulated by the Companies Act (chapter 24:03), Zimbabwe Stock Exchange Act (chapter 24:18), Reserve Bank of Zimbabwe's guideline of 2004, as well as rules of various other professional bodies (Maune, 2014). Maune (2014) claims that corporate governance in Zimbabwe became a major topic for discussion after the local financial crisis of 2003 that saw the near collapse of the financial services sector. This period saw an increase in non-academic trainings, academic educational programs and research on corporate governance in Zimbabwe (Maune, 2014). The study by Maune (in progress) has shown that control of corruption and government effectiveness are insignificant in influence GDP per capita, as their p-values were greater 0.05 level of significance. However, political stability and absence 
of violence/terrorism, regulatory quality, rule of low and voice and accountability are significant at $5 \%$ level of significance, as their p-values were less than 0.05 . Variables rule of law and voice and accountability had negative influence on GDP per capita. However, the overview did not cover the National Code of Corporate Governance that became a reality in 2014. The code is structured in nine chapters. The code recognizes law as the foundational source of corporate governance on which voluntary codes are built. The code has a broader coverage compared to the Reserve Bank of Zimbabwe's 2004 corporate governance guideline which applies to all banking and non-banking institutions that are licensed and supervised by the Central Bank. Table 1 below shows the structure of the National Code of Corporate Governance in Zimbabwe.

Table 1. Zimbabwe's National Code of Corporate Governance structure

\begin{tabular}{c:l}
\hline Chapter & \multicolumn{1}{c}{ Description } \\
\hline 1. & Application of the code and its derivatives \\
\hline 2. & Ownership and control \\
\hdashline 3. & Board of directors and directors \\
\hdashline 4. & Governance of risk \\
\hdashline 5. & Corporate information management and \\
\hdashline 6. & Conflict prevention and resolution \\
\hline 7. & Compliance and enforcement \\
\hdashline 8. & Stakeholder relationship \\
\hline 9. & Role of government in corporate governance \\
\hline
\end{tabular}

\subsection{Measuring corporate governance}

Corporate governance has proved to be difficult to measure and quantify given that there are a few objective indicators that can be systematically collected across firms within a country let alone across countries (African Development Bank, 2011). However, the World Bank under its Doing Business Report has started to publish an 'Investor Protection Index', which index seeks to measure the strength of minority shareholder protection against the misuse of corporate assets by directors pursuing self-satisfying interests (African Development Bank, 2011). World Bank (2017) states that there are two sets of three indices each under which minority investor protection datasets are grouped. These are shown in Table 2 below. World Bank (2017) further states that "the first set of indices focuses on the regulation of conflicts of interest, specifically self-dealing in the context of related-party transactions. A related-party transaction refers to a case where a person has an economic or personal interest in both parties to the transaction. The second set of indices provides a more general view of corporate governance practices, ranging from shareholder rights, protection from share dilution, ownership structure and control of the company to managerial compensation and audit transparency" (p. 66). African Development Bank (2011) confirms that although the World Bank's Investor Protection Index is limited in scope with regards to capturing the full breath of corporate governance issues, it, however, provides a useful snapshot of a very critical aspect of corporate governance, that is, investor protection, that is, comparable across countries. However, very few studies have started using the Investor Protection Index due to non-availability of data especially for developing countries, since the shareholder governance index which is part of the main index emerged in 2014, while conflict of interest regulation index emerged in 2004, as shown in Table 2 below.

Table 2. Investor Protection Indicators

\begin{tabular}{|c|c|c|}
\hline $\begin{array}{l}\text { Extent of } \\
\text { conflict } \\
\text { of interest } \\
\text { regulation } \\
\text { index }\end{array}$ & $\begin{array}{l}\text { extent of disclosure index; } \\
\text { extent of director liability } \\
\text { index; } \\
\text { ease of shareholder suits } \\
\text { index }\end{array}$ & $\begin{array}{l}\text { Measured } \\
\text { since } 2004\end{array}$ \\
\hline $\begin{array}{l}\text { Extent of } \\
\text { shareholder } \\
\text { governance } \\
\text { index }\end{array}$ & $\begin{array}{l}\text { extent of shareholder rights } \\
\text { index; } \\
\text { extent of ownership and } \\
\text { control index; } \\
\text { extent of corporate } \\
\text { transparency index }\end{array}$ & $\begin{array}{l}\text { Measured } \\
\text { since } 2014\end{array}$ \\
\hline
\end{tabular}

Table 3 and Figure 1 below show Zimbabwe's performance against countries such as Israel, Mauritius, South Africa, United Kingdom and the United States of America. These countries were selected on the basis of data availability and as a result of influence from literature which ranks these countries high. A mix of both developing and developed countries was used. Zimbabwe ranks below these countries in most of the indi- 
Source: author (data collected from World Bank's Doing Business database, 2017).
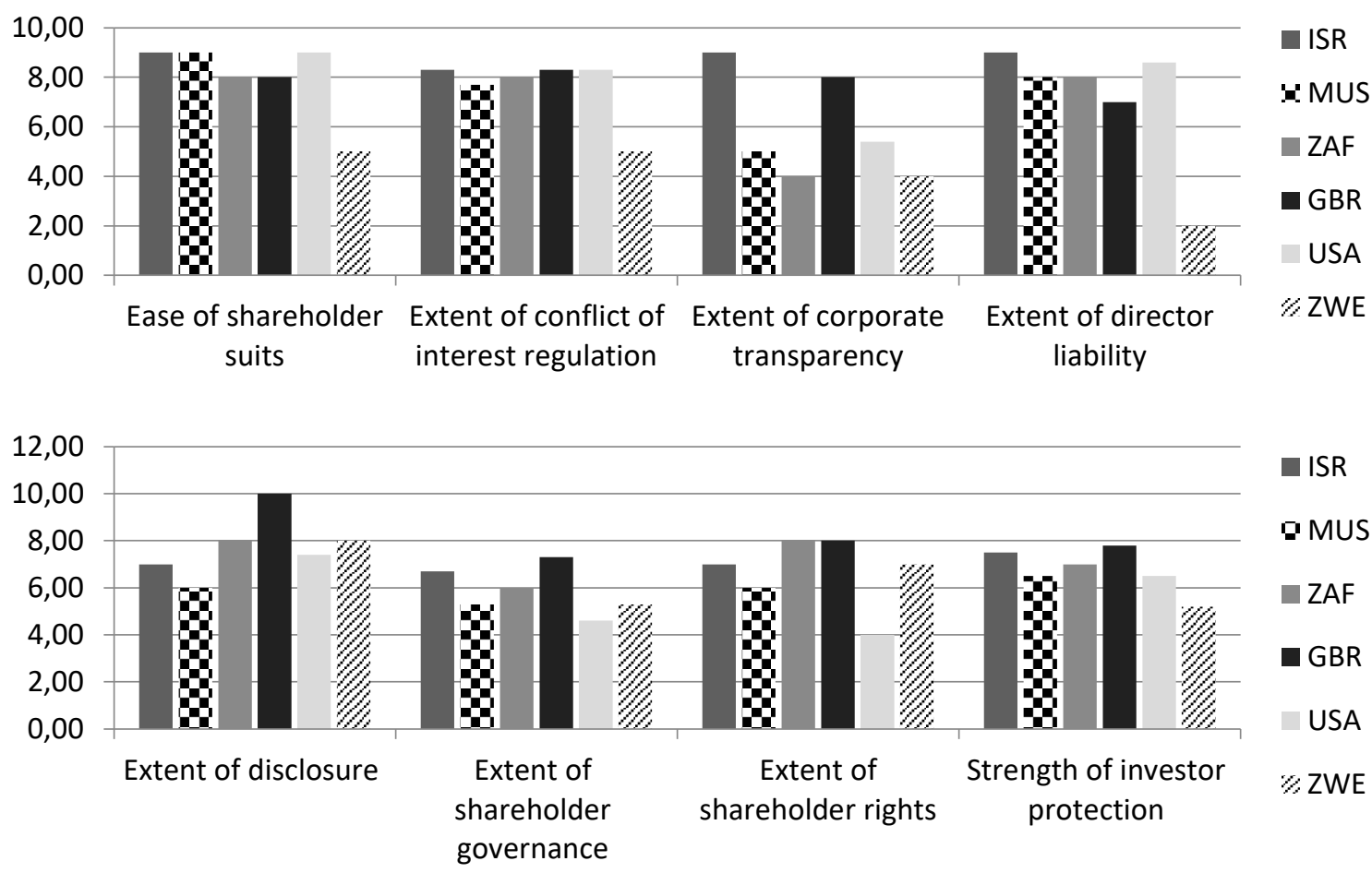

Figure 1. Investor Protection Indices for selected countries as of 2016

ces except in extent of disclosure index in which she ranks above Israel, Mauritius and the United States of America, as well as in extent of shareholder rights in which she ranks above Mauritius and the United States of America. Zimbabwe has, however, recorded its worst performance in the extent of director liability in which she recorded an index of 2 out of 10 with Israel 9, Mauritius 8, South Africa 8, United Kingdom 7 and United States of America 8.60.

\subsection{Empirical evidence}

According to Tiwari (2010), very few studies have been devoted towards investigating the relationship between sound corporate governance and financial success of enterprises. However, Gompers et al. (2003) cited by Tiwari (2010) "find that firms with strong shareholder rights have superior valuation, better profits, and better sales growth" (p. 3). Gompers et al.'s (2003) study used the incidence of 24 governance rules by constructing a "Governance Index" to proxy for the level of share-

Table 3. Investor Protection Indices for selected countries as of 2016

Source: author data collected from World Bank's Doing Business database, 2017.

\begin{tabular}{|c|c|c|c|c|c|c|}
\hline Description & ISR & MUS & ZAF & GBR & USA & ZWE \\
\hline Ease of shareholder suits & 9.00 & 9.00 & 8.00 & 8.00 & 9.00 & 5.00 \\
\hline Extent of conflict of interest regulation & 8.30 & 7.70 & 8.00 & 8.30 & 8.30 & 5.00 \\
\hline Extent of disclosure & 7.00 & 6.00 & 8.00 & 10.00 & 7.40 & 8.00 \\
\hline Extent of director liability & 9.00 & 8.00 & 8.00 & 7.00 & 8.60 & 2.00 \\
\hline Extent of corporate transparency & 9.00 & 5.00 & 4.00 & 8.00 & 5.40 & 4.00 \\
\hline Extent of shareholder governance & 6.70 & 5.30 & 6.00 & 7.30 & 4.60 & 5.30 \\
\hline Extent of shareholder rights & 7.00 & 6.00 & 8.00 & 8.00 & 4.00 & 7.00 \\
\hline Strength of investor protection & 7.50 & 6.50 & 7.00 & 7.80 & 6.50 & 5.20 \\
\hline
\end{tabular}

Note: ISR - Israel, MUS - Mauritius, ZAF - South Africa, GBR - United Kingdom, USA - United States of America and ZWE - Zimbabwe. 
holder rights at about 1500 large firms during the 1990s. Their study employed regression analysis. Tiwari (2010) states that "Claessens (2003) demonstrates a relationship between corporate governance and improved performance of enterprise and finds that the relationship between corporate governance to improved performance of the enterprises is not from better corporate governance to improved performance; rather it is either the other way around or due to some other factors that drives both better corporate governance and better financial performance" (p. 3). Tiwari (2010) finds that performance of corporate governance is significantly negatively related to the economic growth in both specifications and in all models and, hence, it matters not only for the current year, but also it continues to persistent in future also. Tiwari's (2010) study used the log linear model on cross-section of countries.

Brown and Caylor (2004) analyze the US firms with 51 factors, 8 sub-categories for 2327 firms based on dataset of Institutional Shareholder Service (ISS). The study finds that better-governed firms are relatively more profitable, more valuable, and pay out more cash to their shareholders. The study also shows that good governance, as measured using executive and director compensation, is most highly associated with good performance. In contrast, the study shows that good governance as measured using charter/bylaws is most highly associated with bad performance. The study used Person and Spearman correlations to carry out the cross-sectional analysis.

Black et al.'s (2006) study based on a 2001 Korea Stock Exchange survey of 515 Korean companies shows that the overall corporate governance index is an important and likely causal factor in explaining the market value of Korean public companies. Their study shows evidence of a causal relationship between an overall governance index and higher share prices in emerging markets. Black (2001) examines the relationship between corporate governance behavior and market value for a sample of 21 Russian firms. The results of the study show that corporate governance behavior has a powerful effect on market value in a country where legal and cultural constraints on corporate behavior are weak. Johnson et al. (2000) cited in Claessens (2003) state that "there is also country- level evidence that weak legal institutions for corporate governance were key factors in exacerbating the stock market declines during the 1997 East Asian financial crisis" (p. 19). To Claessens (2003), net capital inflows are more sensitive to negative events that adversely affect investors' confidence especially in countries associated with weaker investor protection. Claessens (2003) further argues that in such countries, high risk of expropriation is witnessed in such crisis with lower than expected return of investment realized resulting in the collapse in the country's currency andstock prices.

Lemmon and Lins (2003) state that "Mitton's (2002) [study] also examines how various aspects of corporate governance affect firm performance during the crisis using a smaller sample of approximately 400 [listed] firms from five East Asian countries [Indonesia, Korea, Malaysia, Philippines and Thailand] [and] finds evidence that stock returns during the crisis period are positively related to the cash flow rights of the firm's largest block holder. He finds only weak evidence, however, that the separation of cash flow rights and control rights has an effect on firm performance during the crisis" (pp. 1463-1464).

Similarly, Lemmon and Lins (2003) using a sample of 800 firms in eight East Asian countries find out that the financial crisis negatively impacted firms' investment opportunities, raising the incentives of controlling shareholders to expropriate minority investors. Their study also found that stock returns between $10 \%$ and $20 \%$ and lower were realized in firms where managers had high levels of control rights, but had separated their control and cash flow ownership than others. The study made use of regression analysis. To Claessens (2003), "this provides firm-level evidence consistent with the view that corporate governance helps explain firm performance during a financial crisis" (p. 19). According to Classmen (2003), "this shows that corporate governance can play an important role in determining individual firms' behavior, in particular the incentives of insiders to expropriate minority shareholders during times of distress" (p. 18). Cornett et al.'s (2009) study on the performance of U.S.A.'s publicly-traded banks before and during the financial crisis found that bank performance decreased dramatically during that pe- 
riod. Their study also found that CEO pay-forperformance sensitivity (PPS) and insider ownership weakened significantly just before and during the financial crisis. Of interest was the significant impact corporate governance had on market returns in 2008 for the largest banks and not as much for the smaller banks. To Cornett et al. (2009), those banks which exhibit the strongest corporate governance controls performed best. The study employed regression analysis.

\section{METHODOLOGY}

This article seeks to examine the strength of sound corporate governance on economic growth in Zimbabwe from 1968 to 2015 through an econometric analysis of secondary data. Zimbabwe was selected given its economic challenges, as well as the availability of secondary data.

In the study, data were obtained from the World Bank official websites, that is, the Worldwide Governance Indicators (2016) and the World Development Indicators (2016) databases. The article employed an econometric model to analyze the relationship between corporate governance and economic growth in Zimbabwe from 1968 to 2015. The following multiple regression model was obtained:
$G D P=\beta_{1}+\beta_{2} C C+\beta_{3} G E+\beta_{4} P S A V T+$

$+\beta_{5} R Q+\beta_{6} R L+\beta_{7} V A+u_{t}$,

where $G D P$ being the dependent variable representing economic growth in millions, $C C$ - control of corruption, $G E$ - government effectiveness, PSAVT - political stability and absence of violence/terrorism, $R Q$ - regulatory quality, $R L$ - rule of law and $V A$ - voice and accountability, $u_{t}$ - random disturbance term, and the coefficient estimates $\beta_{1}, \beta_{2}, \beta_{3}, \ldots, \beta_{7}$ are the parameters which quantify the effect of each of these explanatory variables on GDP. Finally, Durbin-Watson test was performed to test for autocorrelation and lack of independence of residuals, factor analysis and step wise regression to determine variables with the greatest effect on GDP has been performed in the model. Why were the six dimensions of governance used rather than the Investor Protection Index? It must be noted that although the Investor Protection Index would have produced better results representing corporate governance at corporate levels (World Bank, 2017), however, the method was not applied due to the unavailability of adequate data for econometric analysis. Therefore, the study had to apply the six governance Worldwide Governance Indicators following studies by Kaufmann, Kraay, ZoidoLobaton and Mastruzzi since 1999 to 2010. The

Table 4. Explanations of variables used in the regression model

Source: World Bank's Worldwide Governance and World Development Indicators databases (2016).

Variables and their explanations

\begin{tabular}{|c|c|}
\hline$G D P$ & $\begin{array}{l}G D P \text { at purchaser's prices is the sum of gross value added by all resident producers in the economy plus any } \\
\text { product taxes and minus any subsidies not included in the value of the products. It is calculated without making } \\
\text { deductions for depreciation of fabricated assets or for depletion and degradation of natural resources }\end{array}$ \\
\hline & $\begin{array}{l}\text { Control of corruption captures perceptions of the extent to which public power is exercised for private gain, } \\
\text { including both petty and grand forms of corruption, as well as "capture" of the state by elites and private interests }\end{array}$ \\
\hline$G E$ & $\begin{array}{l}\text { Government effectiveness captures perceptions of the quality of public services, the quality of the civil } \\
\text { service and the degree of its independence from political pressures, the quality of policy formulation and } \\
\text { implementation, and the credibility of the government's commitment to such policies }\end{array}$ \\
\hline$P S A V T$ & $\begin{array}{l}\text { Political stability and absence of violence/terrorism measures perceptions of the likelihood of political instability } \\
\text { and/or politically-motivated violence, including terrorism }\end{array}$ \\
\hline$R Q$ & $\begin{array}{l}\text { Regulatory quality captures perceptions of the ability of the government to formulate and implement sound } \\
\text { policies and regulations that permit and promote private sector development }\end{array}$ \\
\hline$R L$ & $\begin{array}{l}\text { Rule of law captures perceptions of the extent to which agents have confidence in and abide by the rules of } \\
\text { society, and in particular the quality of contract enforcement, property rights, the police, and the courts, as well } \\
\text { as the likelihood of crime and violence }\end{array}$ \\
\hline$V A$ & $\begin{array}{l}\text { Voice and accountability captures perceptions of the extent to which a country's citizens are able to participate in } \\
\text { selecting their government, as well as freedom of expression, freedom of association, and a free media }\end{array}$ \\
\hline
\end{tabular}

Note: The ranking indicates the country's rank among all countries covered by the aggregate indicator, with 0 corresponding to lowest rank, and 100 to highest rank. 
Worldwide Governance Indicators, that is, the six dimensions of governance measures governance at national level, as this will cascade downwards to corporate and individual levels. These six dimensions were examined to ascertain their impact on economic growth in Zimbabwe as stated above. Table 4 below shows the variables used in the regression model and their explanations.

\section{DATA ANALYSIS AND INTERPRETATION}

In this article, a multiple regression analysis was carried out to examine the impact of sound corporate governance on economic growth in Zimbabwe. The results of the econometric model are presented in Table 5 below.
From Table 5 above, it is evident that the impact of sound corporate governance as measured by the six dimensions of governance on economic growth $(G D P)$ in Zimbabwe is both positive (expected) and negative (not expected). The impact of $C C, G E$ and $R Q$ is negative on the economic growth of Zimbabwe. However, the impact of PSAVT, RL and VA is positive on economic growth of Zimbabwe. The econometric model shows an $R$ of 0.719149 meaning that $0.52 \%$ of the variance $(0.7191492=0.517176)$ in $G D P$ in Zimbabwe is explained by the six explanatory variables acting in concert. $R^{2}$ of 0.517176 indicates that a good deal of the variability of $G D P$ is captured by the regression model. The adjusted $R^{2}$ of 0.446519 (that is, value of coefficient of multiple correlation determination adjusted by degrees of freedom) in the model is not quite high,

Table 5. Regression analysis, influence of sound corporate governance on economic growth in Zimbabwe

Dependent variable: GDP (current US\$ million)

\section{Regression analysis}

\begin{tabular}{l:c} 
OVERALL FIT & \\
\hline Multiple R & 0.719149 \\
\hdashline R Square & 0.517176 \\
\hdashline Adjusted R & 0.446519 \\
\hdashline Standard error & 2210.851 \\
\hdashline Observations & 48 \\
\hline
\end{tabular}

Durbin-Watson test

\begin{tabular}{l|c} 
Alpha & 0.05 \\
\hdashline & \\
\hdashline D-stat & 0.417333 \\
\hdashline D-lower & 1.27087 \\
\hdashline D-upper & 1.82645 \\
\hdashline sig & yes \\
\hline
\end{tabular}

\begin{tabular}{|c|c|c|c|c|c|c|c|}
\hline ANOVA & & & & Alpha & 0.05 & & \\
\hline & df & SS & MS & $F$ & p-value & sig & \\
\hline Regression & 6 & $2.15 \mathrm{E}+08$ & 35776715 & 7.319504 & $2.32 \mathrm{E}-05$ & yes & \\
\hline Residual & 41 & $2 \mathrm{E}+08$ & 4887860 & & & & \\
\hline \multirow[t]{2}{*}{ Total } & 47 & $4.15 \mathrm{E}+08$ & & & & & \\
\hline & coeff & std. err. & t-stat. & p-value & lower & upper & vif \\
\hline Intercept & 1577.059 & 2937.735 & 0.536828 & 0.594288 & -4355.82 & 7509.937 & \\
\hline $\mathrm{CC}$ & -465.433 & 149.1723 & -3.1201 & 0.003305 & -766.692 & -164.173 & 69.90417 \\
\hline GE & -180.219 & 177.31 & -1.01641 & 0.315395 & -538.304 & 177.8653 & 92.96515 \\
\hline PSAVT & 359.0503 & 125.6009 & 2.858659 & 0.006659 & 105.3941 & 612.7066 & 5.383885 \\
\hline $\mathrm{RQ}$ & -72.533 & 930.5105 & -0.07795 & 0.938247 & -1951.74 & 1806.671 & 496.0083 \\
\hline $\mathrm{RL}$ & 368.9411 & 791.6118 & 0.466063 & 0.643637 & -1229.75 & 1967.634 & 710.0842 \\
\hline VA & 499.7412 & 294.8765 & 1.694748 & 0.097707 & -95.7739 & 1095.256 & 87.35562 \\
\hline
\end{tabular}


Table 6. Regression analysis, factor analysis - principal component extraction

\begin{tabular}{|c|c|c|c|c|c|c|c|}
\hline \multicolumn{8}{|c|}{ Descriptive statistics } \\
\hline & GDP & $\mathrm{CC}$ & GE & PSAVT & RQ & $\mathbf{R} \mathbf{L}$ & VA \\
\hline Mean & 6713.651 & 31.71295 & 35.5439 & 24.16084 & 13.70509 & 18.34999 & 23.71545 \\
\hline Stddev & 2971.72 & 18.07482 & 17.53628 & 5.957519 & 7.718513 & 10.85558 & 10.22153 \\
\hline Skewness & 0.709217 & -0.80366 & -0.91869 & -1.19226 & -0.84989 & -0.86477 & -0.8809 \\
\hline Kurtosis & 0.896265 & -1.33443 & -1.08321 & -0.13918 & -1.25793 & -1.24506 & -1.13232 \\
\hline \multicolumn{8}{|c|}{ Correlation matrix } \\
\hline & GDP & $\mathrm{CC}$ & GE & PSAVT & RQ & $\mathbf{R L}$ & VA \\
\hline GDP & 1 & -0.44182 & -0.43687 & -0.11383 & -0.40891 & -0.40147 & -0.37943 \\
\hline CC & -0.44182 & 1 & 0.985918 & 0.837689 & 0.973042 & 0.977151 & 0.989572 \\
\hline GE & -0.43687 & 0.985918 & 1 & 0.801544 & 0.982156 & 0.987605 & 0.985911 \\
\hline PSAVT & -0.11383 & 0.837689 & 0.801544 & 1 & 0.778687 & 0.793684 & 0.853585 \\
\hline RQ & -0.40891 & 0.973042 & 0.982156 & 0.778687 & 1 & 0.998355 & 0.973031 \\
\hline RL & -0.40147 & 0.977151 & 0.987605 & 0.793684 & 0.998355 & 1 & 0.979746 \\
\hline \multirow[t]{2}{*}{ VA } & -0.37943 & 0.989572 & 0.985911 & 0.853585 & 0.973031 & 0.979746 & 1 \\
\hline & 0.871377 & 4.749852 & 4.717378 & 3.322048 & 4.628506 & 4.677917 & 4.73054 \\
\hline
\end{tabular}

that is, below $50 \%$ indicating that the explanatory power of the variables included in the analysis is not considerably high as would have been expected. F-test of 0.000023235 shows that the model is significant at $5 \%$ level of significance showing a good fit for the data. On the one hand, variables $C C$ and PSAVT have the greatest influence on $G D P$ in Zimbabwe, as they are statistically significant at $5 \%$ level of significance, that is, their $\mathrm{p}$ - values are less than 0.05 . On the other hand, variables $G E, R Q, R L$ and $V A$ are not statistically significant at $5 \%$ level of significance, as their $\mathrm{p}$ values are greater than 0.05 . On the whole, the results are not consistent with the results by Maune (in progress) in a study that involved 13 countries in sub-Saharan Africa covering the period 2005 to 2011. In Maune (in progress), $C C, G E$ are insignificant to $G D P$ per capita though positive. To

Table 7. Stepwise regression analysis

\begin{tabular}{l|c|c|c|c|c|c}
\multicolumn{1}{c}{ ANOVA } & \multicolumn{5}{c}{ Alpha } \\
\hline & df & SS & MS & F & p-value & sig \\
\hline Regression & 3 & $2.02 \mathrm{E}+08$ & 67389305 & 13.92768 & $1.61 \mathrm{E}-06$ & yes \\
Residual & 44 & $2.13 \mathrm{E}+08$ & 4838515 & & & \\
\hdashline Total & 47 & $4.15 \mathrm{E}+08$ & & & & \\
\hline
\end{tabular}

\begin{tabular}{|c|c|c|c|c|c|c|c|}
\hline & coeff & std. err. & t-stat. & p-value & lower & upper & vif \\
\hline Intercept & 260.9859 & 1865.487 & 0.139902 & 0.889376 & -3498.66 & 4020.629 & \\
\hline $\mathrm{CC}$ & -487.118 & 123.7787 & -3.9354 & 0.000292 & -736.578 & -237.659 & 48.62117 \\
\hline PSAVT & 347.98 & 103.8335 & 3.351325 & 0.00166 & 138.7172 & 557.2427 & 3.716996 \\
\hline VA & 568.9594 & 229.464 & 2.479515 & 0.017058 & 106.5051 & 1031.414 & 53.43754 \\
\hline
\end{tabular}


Kaufmann et al. (2007), $G E$ should by construction be positively correlated with growth. A decrease in government personnel quality lowers growth. $G E$ is critical in measuring government personnel quality. Hence, the results of this study must be a cause for concern for government and its institutional quality. Their $\mathrm{p}$-values are greater than 0.05 at $5 \%$ level of significance. However, $P S A V T, R Q, R L$ and $V A$ are significant with p-values less than 0.05 at $5 \%$ level of significance. $R L$ and $V A$, however, have negative influence on $G D P$, per capita. In this current study, $C C$ and $P S A V T$ are significant variables in influencing $G D P$ as their p-values are less than 0.05 . The inconsistency in the results for both studies might be as a result of different periods being covered, as well as geographical areas covered.

Durbin-Watson test of correlation among the residuals reveals a substantial autocorrelation. From the results in Table 5 above, $d<d l(0.41733<1.27087)$ meaning the null hypothesis is rejected and the existence of a positive autocorrelation presumed at $5 \%$ level of significance. The stepwise regression in Table 7 above shows that $C C, P S A V T$ and $V A$ are statistically significant at $5 \%$ level of significance with $\mathrm{p}$-values less than 0.05 thereby greatly impacting GDP in Zimbabwe with $C C$ having a negative impact, while $P S A V T$ and $V A$ impacting $G D P$ in a positive way. This shows that of the five governance variables, only three are statistically significant in influencing $G D P$ in Zimbabwe for the period under consideration. These variables by construction must be positively correlated with growth, hence, the need to serious look at each variable to ascertain the causes of its behavior. In comparison with Maune's (in progress) study, $P S, R Q, R L$ and $V A$ are statistically significant though $R L$ and $V A$ are negative, while $P S A V T$ and $P S$ have positive influence on GDP. The factor analysis in Table 6 shows the descriptive statistics, that is, the mean, standard deviation from the mean, skewness, as well as the kurtosis and the correlation matrix at $5 \%$ level of significance showing individual variables' correlation with one another. The results show that all the variables are negatively correlated with $G D P$ at less than 0.5. However, when these variables are compared with each other except with GDP, they are showing positive correlation above 0.7 .

It must be noted that although there is positive correlation between sound corporate governance and economic growth, a lot needs to be done if Zimbabwe is to realize the positive gains that come with sound corporate governance. A number of reforms needs to be done to raise the country's percentile ranking as determined the World Bank's Worldwide Governance Indicators. The country has taken a positive path through the introduction of the National Code of Corporate Governance in 2016, ease of doing business reforms, realignment of the companies act and other property rights laws.

In absolute numbers, Zimbabwe has been ranking below $50 \%$ in all the six dimensions since 1968 to 2015 with the period 1968 to 1999 ranking above $18 \%$, but below $48 \%$. Period 2000 to 2015 has seen ranking levels averaging between $4 \%$ and $17 \%$ on all the six dimensions of governance. Although there a quite a number of factors that have contributed to the drop in ranking such as the land reform program, economic sanctions and the financial crisis (both global and local), the country has not done much towards promoting sound corporate governance. A study by Maune (2014) shows that nothing much has been done towards promoting sound corporate governance in Zimbabwe. However, a few reforms were done after the financial crisis that saw the near collapse of the financial sector and the whole economy from 2004 to 2008 before the country adopted the multicurrency regime.

\section{CONCLUSION}

The study examined the impact of sound corporate governance on economic growth in Zimbabwe using an econometric model. GDP was used as a dependent variables representing economic growth with the explanatory variable denoted by the six dimensions of governance as given by the World Bank's Worldwide Governance Indicators, that is, control of corruption, government effectiveness, political 
stability and absence of violence/terrorism, regulatory quality, rule of law and voice and accountability. A multiple regression model was developed to analyze the impact of sound corporate governance on economic growth in Zimbabwe. The study found that sound corporate governance was significantly positively and negatively related to economic growth in Zimbabwe for the period 1968 to 2015 at 5\% level of significance. It was also found that $P S A V T, R L$ and $V A$ have a positive impact on $G D P$ with $C C, G E$ and $R Q$ having negative impact on $G D P$ in Zimbabwe. $C C$ and $P S A V T$ have greater impact on $G D P$ in Zimbabwe with p-values less than 0.05. GE, RQ, RL and $V A$ were found to have no statistical significant influence on $G D P$ in Zimbabwe with p-values greater than 0.05 . On the whole, the model was statistically significant with $5 \%$ level of significance with a p-value of 0.000023235 at $5 \%$ level of significance. The stepwise regression analysis shows that $C C, P S A V T$ and $V A$ have greater significance on $G D P$ in Zimbabwe with p-values less than 0.05 . The results shows $C C$ to have a significant negative impact on $G D P$ in Zimbabwe. These results are very critical to policy-makers and government at large as by construction the governance variables must be positively corrected with growth, but, in this case, the results of the regression model shows that PSAVT, RL and VA are positively correlated with growth with PSAVT showing significant influence with a p-value less than 0.05 at $5 \%$ level of significance. Variables $C C, G E$ and $R Q$ are inconsistent with the norm. The author is, however, aware of the limitations of this study using the World Bank worldwide governance indicators and the need to complement these with other macroeconomic variables that have influence on the country's $G D P$. These could act as control variables. There is much room for further future research in this area. However, it is the author's hope that this study will go a long way in influencing policy planning and formulation, as well as stimulating future research.

\section{REFERENCES}

1. African Development Bank (2011). Private Sector Development as an Engine of Africa's Economic Development: African Development Report, AFDB, Tunis.

2. Aggarwal, R., Erel, I., Stulz, R., \& Williamson, R. (2009). Differences in Governance Practice between U.S. and Foreign Firms: Measurement, Causes, and Consequences. Review of Financial Studies, 22, 3131-3169.

3. Ammann, M., Oesch, D., \& Schmid, M. (2011). Corporate Governance and Firm Value: International Evidence. Journal of Empirical Finance, 18(1), 36-55.

4. Arora, R. U. (2014). Access to Finance: An Empirical Analysis. European Journal of Development Research, 26, 798-814.

5. Asker, J., Farre-Mensa, J., \& Ljungqvist, A. (2015). Corporate Investment and Stock Market Listing: A Puzzle? Review of Financial Studies, 28(2), 342-90.

6. Ates, A., Gurarda, S., \& Ozsoz, E. (2014). Ownership Structure and
Corporate Governance in the Case of Turkey. MPRA Paper 58293.

7. Bebchuk, L. (2013). The Myth that Insulating Boards Serves LongTerm Value. Columbia Law Review, 113(6), 1637-1694.

8. Bebchuk, L., Kraakman, R., \& Triantis, G. (1999). Stock Pyramids, Cross-Ownership and Dual Class Equity: The Creation and Agency Costs of Separating Control from Cash Flow Rights. Discussion Paper 249, Harvard Law School, Cambridge, MA.

9. Black, B. (2001). The Corporate Governance Behavior and Market Value of Russian Firms. Emerging Markets Review, 2, 89-108.

10. Black, B., Hasung J., \& Woochan, K. (2006). Does Corporate Governance Affect Firms' Market Values? Evidence from Korea. Journal of Law, Economics and Organization, 22, 366-413.

11. Brown, L., \& Caylor, M. (2004). Corporate governance study links bad boards to higher risks and increased volatility. A Study Commissioned by ISS, February 4.
12. Brown, L., \& Caylor, M. (2009). Corporate Governance and Firm Operating Performance. Review of Quantitative Finance and Accounting, 32(2), 129-144.

13. Charreaux, G. (1997). La creation de valeur de l'entreprise. Economica, Paris, France, 10.

14. Claessens, S. (2003). Corporate Governance and Development. Global Corporate Governance Forum 1, World Bank, Washington, D.C.: USA.

15. Claessens, S. (2006). Corporate Governance and Development. The World Bank Research Observer, 21(1), 91-122.

16. Cornett, M. M., McNutt, J. J., \& Tehranian, H. (2009). The Financial Crisis: Did Corporate Governance affect the performance of publicly-traded U.S. Bank Holding companies? Journal of Corporate Finance, 15, 412-430.

17. De Paula, G. M. (2003). Governança Corporativa no Brasil e México: Estrutura Patrimonial. Práticas e PolíticasPúblicas, Santiago do Chile, Cepal, 7-8. 
18. Denis, D., \& Serrano, J. (1996) Active Investors and Management Turnover Following Unsuccessful Control Contests. Journal of Financial Economics, 40(2), 239.

19. Dyck, A., \& Zingales, L. (2004). Private Benefits of Control: An International Comparison. Journal of Finance, 59(2), 537-600.

20. Eisenberg, M. (1993). An Overview of the Principles of Corporate Governance. Business Lawyer, 48, 1271.

21. Gompers, P., Ishii, J., \& Metrick, A. (2003). Corporate governance and equity prices. The Quarterly Journal of Economics, 118, 107-155.

22. Grossman, S., \& Hart, O. (1982). Corporate Financial Structure and Managerial Incentive. In The Economics of Information and Uncertainty (pp. 107-140). Chicago: University of Chicago Press.

23. Holderness, C. (2003). A Survey of Blockholders and Corporate Control. Economic Policy Review, Federal Reserve Bank of New York, 9(1) Special Issue, 51-63.

24. Johnson, S., Boone, P., Breach, A., \& Friedman, E. (2000). Corporate governance in the Asian financial crisis. Journal of Financial Economics, 58, 141-186.

25. Kaufmann, D., Kraay, A., \& Mastruzzi, M. (2007). Growth and Governance: A Reply/Rejoinder. Journal of Politics, 69(2), 555-562.

26. Kaufmann, D., Kraay, A., \& Mastruzzi, M. (2009). The Worldwide Governance Indicators: Methodology and Analytical Issues. World Bank Draft Policy Research Working Paper, Washington, D.C.

27. Kaufmann, D., Kraay, A., \& ZoidoLobatón, P. (1999). Aggregating Governance Indicators. World Bank
Policy Research Working Paper, 2195, Washington, D.C.

28. Klapper, L., \& Love, I. (2004). Corporate Governance, Investor Protection, and Performance in Emerging Markets. Journal of Corporate Finance, 10(5), 703-728.

29. Kutan, A. M. (2015). Finance, Development, and Corporate Governance. Emerging Economies, Emerging Markets Finance and Trade, 51(1).

30. La Porta, R., Lopez-de-Silanes, F., Shleifer, A., \& Vishny, R. (1996). Law and Finance. Harvard Institute of Economic Research Working Paper 1768, Harvard University Institute of Economic Research, Cambridge, MA.

31. La Porta, R., Lopez-de-Silanes, F., Shleifer, A., \& Vishny, R. (2000). Investor Protection and Corporate Governance. Journal of Financial Economics, 58(1-2), 3-27.

32. Lan, L., \& Varottil, U. (2015). Shareholder Empowerment in Controlled Companies: The Case of Singapore. In The Research Handbook of Shareholder Power, edited by Randall Thomas and Jennifer Hill, Cheltenham: Edward Elgar.

33. Lemmon, M. L., \& Lins, K. V. (2003). Ownership structure, corporate governance, and firm value: evidence from the East Asian Financial crisis. Journal of Finance, 58(4), 1445-1468.

34. Liljeblom, E., \& Maury, B. (2015). Shareholder Protection, Ownership, and Dividends: Russian Evidence. Emerging Markets Finance and Trade.

35. Maune, A. (2014). Corporate Governance in Zimbabwe: An Overview of its Current State. Journal of Asian Economic and Financial Review, 5(1), 167-178.
36. Maune, A. (in progress) Corporate Governance and Economic Growth in subSaharan Africa: An analysis. Journal of Panoeconomicus, Forthcoming.

37. Mitton, T. (2002). A crossfirm analysis of the impact of corporate governance on the East Asian financial crisis. Journal of Financial Economics, 64, 215-241.

38. Okpara, J. (2011). Corporate Governance in a Developing Economy: Barriers, Issues, and Implications for Firms. The International Journal of Business in Society, 11(2), 184-199.

39. Pass, C. (2004). The revised combined code and corporate governance: an empirical survey of 50 large UK companies. Managerial Law, 48, 467-478.

40. Posner, R. (1983). The Economics of Justice. Cambridge: Harvard University Press.

41. Rupeika-Apoga, R. (2014). Access to Finance: Baltic Financial Markets. Procedia Economics and Finance, 9, 181-92.

42. Shleifer, A., \& Vishny, R. (1986). Large Shareholders and Corporate Control. Journal of Political Economy, 94(3), 461-488.

43. Tiwari, A. K. (2010). 'Corporate Governance and Economic Growth. Economics Bulletin, 30(4), 2825-2841.

44. Weimer, J., \& Pape, J. C. (1999). A taxonomy of system of Corporate Governance. Corporate Governance, 7, 152-166.

45. World Bank (2017). Doing Business 2017: Equal Opportunity for All. Washington, D. C.: World Bank. https://doi. org/10.1596/978-1-4648-0948-4 